\title{
ANALISA KOMPUTASI KEMUNCULAN DAN KEPUNAHAN KOSAKATA BAHASA INDONESIA BERDASARKAN CORPUS
}

\author{
Muhammad Fachrul Kurniawan ${ }^{1}$, Faisal Rahutomo ${ }^{2}$, Ridwan Rismanto ${ }^{3}$ \\ ${ }^{1,2,3}$ Teknik Informatika, Teknologi Informasi, Polteknik Negeri Malang \\ 1achrul.xiia1.26@gmail.com, ${ }^{2}$ faisal.polinema@gmail.com, ${ }^{3}$ ridwan@ polinema.ac.id
}

\begin{abstract}
Abstrak
Bahasa Indonesia merupakan bahasa yang biasa kita gunakan sehari-hari. Penelitian ini tertarik untuk mengungkap seberapa besar tingkat kepunahan dan kemunculan kosakata baru di dalam pengucapan sehari-hari karena juga terdapat bahasa baru yang sering digunakan oleh anak-anak muda jaman sekarang. Penelitian ini bertujuan untuk menganalisa hubungan antara kosakata asing maupun kosakata yang telah punah terhadap waktu sehingga kita dapat mengetahui penggunaan kosakata asing maupun kosakata yang punah dari waktu ke waktu. disini peneliti menggunakan data kata dari berita online untuk diteliti selama enam bulan dari berbagai situs berita online untuk menganalisa peningkatan maupun penurunan kosakata tersebut. Metode analisis yang digunakan adalah analisis regresi sederhana. Dari hasil penelitian ini, menunjukan bahwa terdapat tingkat penurunan kata asing yang digunakan pada berita online dari minggu ke minggu, sedangkan kepunahan bahasa Indonesia pada berita online cenderung mengalami peningkatan
\end{abstract}

Kata Kunci: kata punah, kata asing, analisa regresi

\section{Pendahuluan}

Bahasa Indonesia merupakan bahasa kesatuan yang dapat menyatukan seluruh rakyat Indonesia, namun seiring berjalannya waktu bahasa Indonesia baku mulai tersisih dengan bahasa-bahasa asing maupun bahasa dari daerah-daerah yang ada diseluruh Indonesia. Masyarakat lebih sering menggunakan bahasa dari daerah masing-masing dikarenakan pengucapannya mudah mereka ingat karena banyak yang menggunakan bahasa dari tiaptiap daerah daripada menggunakan bahasa Indonesia yang baku. Bukan hanya bahasa daerah saja yang sering digunakan sebagai bahasa obrolan sehari-hari, bahasa asing juga sering digunakan untuk komunikasi kita sehari-hari. Sehingga membuat bahasa Indonesia menjadi asing bagi kita karena jarang diucapkan bahkan ada yang sampai punah karena tidak pernah diucapkan oleh kebanyakan orang.

Penelitian ini tertarik untuk mengungkap seberapa besar tingkat kepunahan dan kemunculan kosakata baru di dalam pengucapan sehari-hari karena juga terdapat bahasa baru yang sering digunakan oleh anak-anak muda jaman sekarang. Bahasa baru itu pulalah yang sering digunakan dalam obrolan sehari-hari, contohnya seper ti

baper, alay, lebay, dan lain sebagainya. Selain bahasa baru juga terdapat berbagai macam bahasa Indonesia baku yang terdapat pada Kamus Besar Bahasa Indonesia (KBBI), namun jarang atau bahkan tidak pernah kita jumpai.

Maka dari itu penelitian ini mengusulkan suatu sistem komputasi yang memungkinkan kita bisa menganalisa kosakata bahasa Indonesia yang kita gunakan sehari-hari untuk menentukan kemungkinan bahasa yang jarang kita ucapkan atau bahkan tidak pernah terucapkan sama sekali. Selain itu sistem ini diharapkan juga dapat menemukan kata-kata yang tidak ada pada Kamus Besar Bahasa Indonesia namun sering digunakan untuk percakapan sehari-hari. Dalam proses analisa terkomputasi ini penulis menggunakan data dari berita online.

\section{Landasan Teori}

\subsection{Operasi Teks}

Operasi teks diperlukan untuk memperoleh kata-kata yang bermakna untuk mereprensentasikan sebuah dokumen. Operasi teks yang dilakukan disebut praproses dokumen yang meliputi tahapantahapan berikut:

1. Analisis leksikal teks dengan tujuan menghilangkan angka, tanda hubung, tanda baca, dan besar huruf.

2. Penghilangan stopword dengan tujuan memfilter kata yang memiliki nilai rendah untuk keperluan retrieval.

3. Stemming kata yang tersisa dengan tujuan menghilangkan imbuhan.

4. Pemilihan term untuk digunakan sebagai elemen pengindeksan

\subsection{Tokenizing}

Istilah token didefinisikan sebagai unit terkecil dari sebuah teks atau dapat juga merupakan suatu 
kumpulan dari string alphanumerik. Suatu unit terkecil yang digunakan disini adalah sebuah kata tunggal yang disebut juga sebagai term. Sebuah kata tunggal dapat berisi sekumpulan string alphanumerik. Di dalam proses ini terjadi pemotongan dokumen menjadi daftar kata yang berdiri sendiri sebelum dilakukan proses selanjutnya.

\subsection{Analisa Regresi}

Analisa Regresi adalah suatu metode analisis statistik yang digunakan untuk melihat pengaruh antara dua atau lebih variabel. Hubungan variabel tersebut bersifat fungsional yang diwujudkan dalam suatu model matematis. Pada analisis regresi, variabel dibedakan menjadi dua bagian, yaitu variabel respons (response variable) atau biasa juga disebut variabel bergantung (dependent variable) dan variabel explanory atau biasa disebut penduga (predictor variable) atau disebut juga variabel bebas (independent variabel).

Analisis regresi digunakan hampir pada semua bidang kehidupan, baik dalam bidang pertanian, ekonomi dan keuangan, industri dan ketenagakerjaan, sejarah, pemerintahan, ilmu lingkungan, dan sebagainya. Kegunaan analisis regresi diantaranya untuk mengetahui variabelvariabel kunci yang memiliki pengaruh terhadap suatu variabel bergantung, pemodelan, serta pendugaan (estimation), atau peramalan (forecasting).

Model persamaan regresi linear adalah seperti berikut ini:

$$
\mathbf{Y}=\mathbf{a}+\mathbf{b X}
$$

Dimana:

$\mathrm{Y}=$ Variabel Response atau Variabel Akibat (Dependent)

$\mathrm{X}=$ Variabel Predictor atau Variabel Faktor

Penyebab (Independent)

$\mathrm{a}=$ konstanta

$\mathrm{b}=$ koefisien regresi (kemiringan); besaran

Response yang ditimbulkan oleh Predictor.

Tahap Analisa Regresi:

1. Penentuan Tujuan

2. Identifikasikan Variabel Penyebab dan Akibat

3. Pengumpulan Data

4. Hitung a dan $\mathrm{b}$ berdasarkan rumus Regresi Linear Sederhana

$$
\begin{aligned}
\mathbf{a} & =\frac{(\Sigma \mathbf{y})\left(\Sigma \mathbf{x}^{2}\right)-(\Sigma \mathbf{x})-(\Sigma \mathbf{x y})}{\mathbf{n}\left(\Sigma \mathbf{x}^{2}\right)-(\Sigma \mathbf{x})^{2}} \\
\mathbf{b} & =\frac{\mathbf{n}(\Sigma \mathbf{x y})-(\Sigma \mathbf{x})}{\mathbf{n}\left(\Sigma \mathbf{x}^{2}\right)-(\Sigma \mathbf{x})^{2}}(\Sigma \mathbf{y})
\end{aligned}
$$

5. Buat Model Persamaan Regresi

$$
\mathbf{Y}=\mathbf{a}+\mathbf{B} \mathbf{x}
$$

\section{Analisis dan Perancangan}

Pada bagian ini dibahas metodologi yang digunakan peneliti dalam pembuatan Analisa Komputasi Kemunculan dan Kepunahan Kosakata Bahasa Indonesia Berdasarkan Corpus Berita Online. Metode penenlitian yang digunakan adalah metode prototype.

Proses kegiatan yang ada pada metode prototyping dapat dijelaskan pada Gambar 1 sebagai berikut.

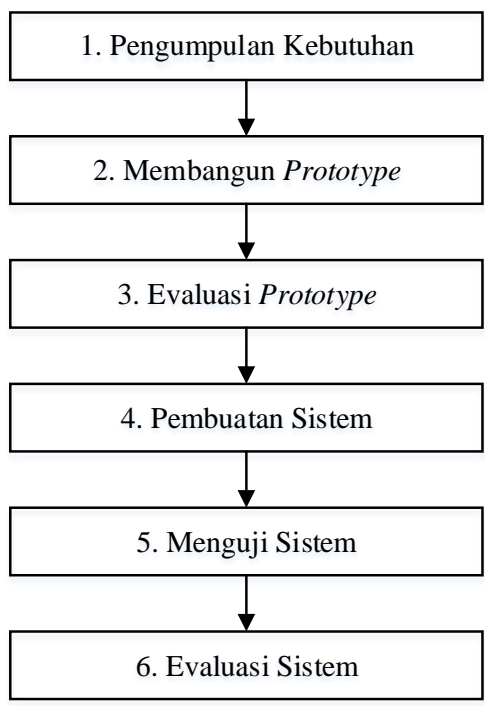

Gambar 1. Prototype Model

Berikut merupakan penjelasan dari setiap tahap prototype.

1. Pengumpulan Kebutuhan

Pada tahap ini hal yang dilakukan adalah mendefinisikan kebutuhan perangkat, sistem ataupun data yang diperlukan untuk menganalisa kemunculan dan kepunahan kosakata bahasa Indonesia.

2. Membangun Prototype

Pada tahap ini dimulai perancangan sementara pada sistem yang dibuat, sehingga user dapat melihat fungsi-fungsi dari program yang dibuat.

3. Evaluasi Prototype

Mengevaluasi perancangan yang telah dibuat. Jika telah sesuai dengan yang diinginkan maka dilanjutkan ke tahap berikutnya. Jika belum sesuai maka mengulang pada tahap 1, 2, dan 3.

4. Pembuatan Sistem

Proses pembuatan sistem yang sesuai dengan perancangan. Dari beberapa perancangan yang sudah dijelaskan pada tahap sebelumnya, maka pada tahap ini mulai mengimplememtasikan hasil perancangan tersebut ke dalam sistem. 
5. Menguji Sitem

Pengujian dilakukan dengan cara menghitung akurasi kebenaran dari pengelompokkan data berita.

6. Evaluasi Sistem

Mengevaluasi dan dan memperbaiki sistem jika sistem yang dibuat belum berjalan sesuai yang diharapkan. Kemungkinan adanya bug/error pada tahap pengujian sistem, maka pada tahap ini akan diselesaikan.

Dibawah ini merupakan Gambaran umum dari system Analisa komputasi kemunculan dan kepunahan kosakata bahasa Indonesia :

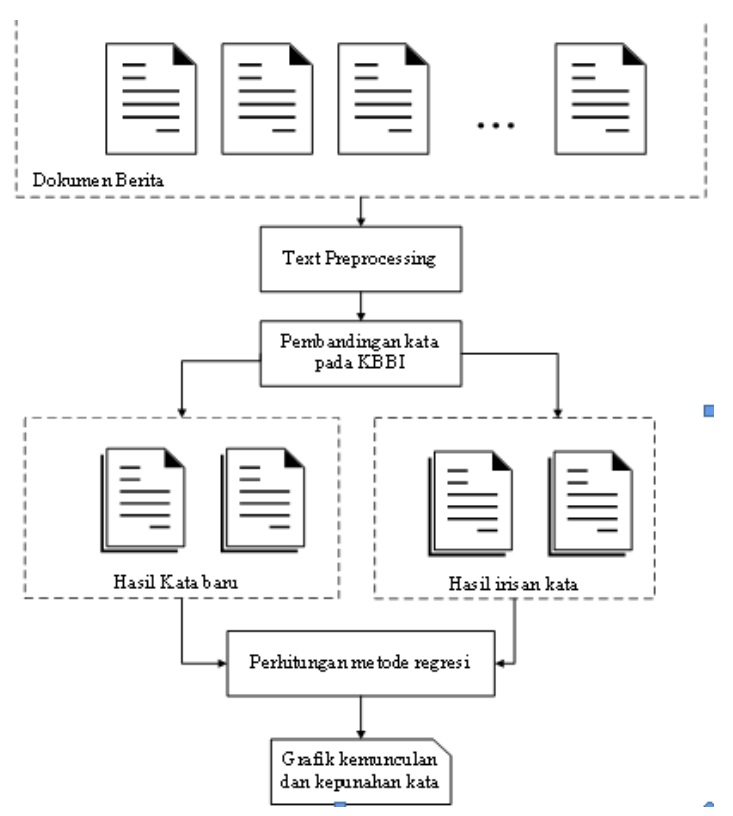

\subsection{Metode Pengumpulan Data}

Data-data yang didapatkan untuk melakukan penelitian yaitu melalui hasil crawling data berita dari situs berita terkait. Data tersebut diperoleh per hari selama 6 (enam) bulan.

\subsection{Perancangan Sistem}

Perancangan sistem merupakan suatu proses desain sistem dalam penggambaran dan pembuatan sketsa interface aplikasi hingga perhitungan dari metode itu sendiri yakni Regresi linear. Rancangan ini sendiri akan terbagi menjadi tiga yakni perancangan perhitungan metode, perancangan proses dalam bentuk flowchart, dan perancangan user interface atau mockup dari aplikasi ini.

\subsection{Flowchart System}

Flowchart merupakan sebuah diagram yang digunakan untuk menjelaskan alur dari sebuah sistem dengan menggunakan simbol-simbol yang telah ditentukan dan saling terhubung.

Dibawah ini merupakan flowchart system :

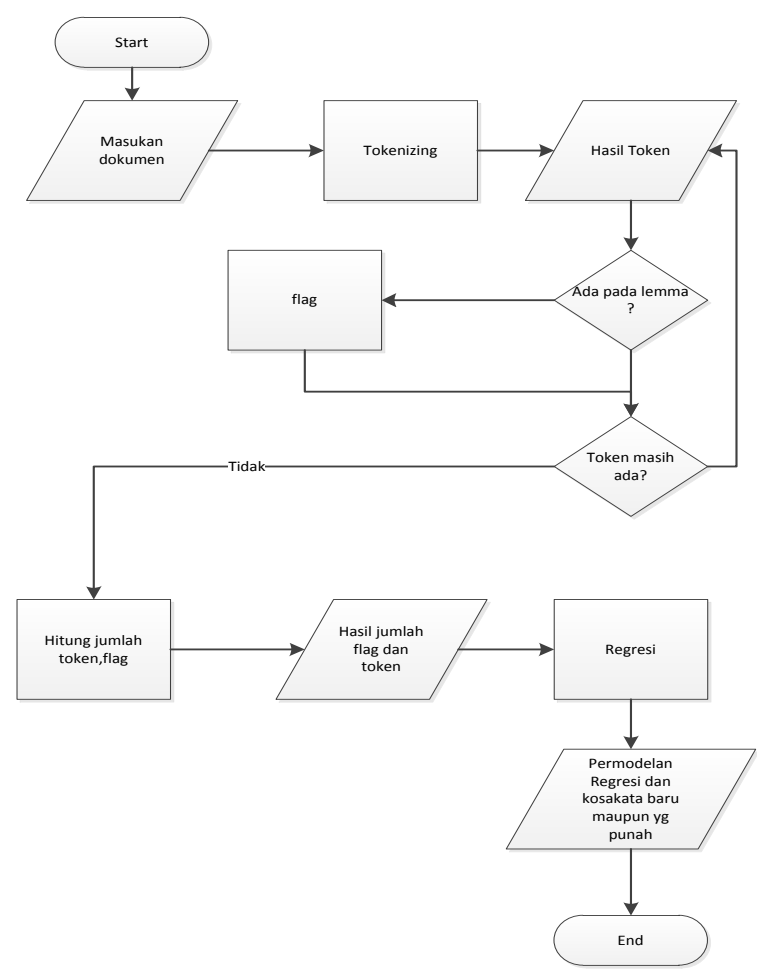

\subsection{Perancangan Data Flow Diagram (DFD)}

DFD adalah sebuah teknis grafis yang menggambarkan aliran informasi dan transformasi yang diaplikasikan pada saat data bergerak dari input menjadi output.DFD dapat dipisahkan ke dalam level-level yang merepresentasikan aliran data yang lebih detail (Pressman, 2002).

Berikut merupakan rancangan DFD level 0 :

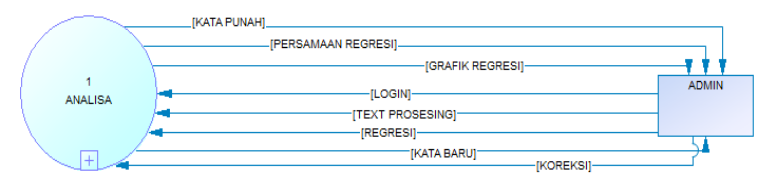

Gambar 2. DFD Level 0 (Context Diagram)

\section{Uji Coba dan Pembahasan}

Pada bab pengujian dan pembahasan ini akan dilakukan tahapan untuk menguji hasil dari implementasi sistem yang telah dilakukan.

\subsection{Pengujian Sistem}

Pengujian sistem ini dilakukan dengan cara menjalankan aplikasi secara detail pada setiap menu yang ada, dengan tujuan untuk mengetahui menu atau fitur mana yang sudah berfungsi dengan baik maupun yang tidak berfungsi sesuai dengan sebagaimana mestinya.

\subsection{Pembahasan}

Dari penelitian yang telah dilakukan. Disini akan dibahas mengenai analisa kosakata Bahasa Indonesia terhadap waktu. 
Berikut ini merupakan bahasan dari analisa kata baru terhadap waktu :

\begin{tabular}{|c|c|c|c|c|c|}
\hline \multicolumn{6}{|c|}{ Tabel Kemunculan kata baru Tiap Minggu } \\
\hline No & Waktu (X) & Kata Baru (Y) & $\mathrm{X}^{2}$ & $\mathbf{Y}^{2}$ & XY \\
\hline 1 & 1 & 26126 & 1 & 682567876 & 26126 \\
\hline 2 & 2 & 33634 & 4 & 1131245956 & 67268 \\
\hline 3 & 3 & 26281 & 9 & 690690961 & 78843 \\
\hline 4 & 4 & 24407 & 16 & 595701649 & 97628 \\
\hline 5 & $\overline{5}$ & $30 \$ 49$ & 25 & 951660801 & 154245 \\
\hline 6 & $\overline{6}$ & 30583 & 36 & 935319889 & 183498 \\
\hline 7 & 7 & 30313 & 49 & 918877969 & 212191 \\
\hline 8 & $\overline{8}$ & 31312 & 64 & 980441344 & 250496 \\
\hline 9 & 9 & 32136 & 81 & 1032722496 & 289224 \\
\hline 10 & 10 & 31390 & 100 & 985332100 & 313900 \\
\hline 11 & 11 & 30409 & 121 & 924707281 & 334499 \\
\hline 12 & 12 & 30883 & 144 & 953759689 & 370596 \\
\hline 13 & 13 & 28078 & 169 & 788374084 & 365014 \\
\hline 14 & 14 & 30766 & 196 & 946546756 & 430724 \\
\hline 15 & 15 & 29621 & 225 & 877403641 & 444315 \\
\hline 16 & 16 & 28545 & 256 & 814817025 & 456720 \\
\hline 17 & 17 & 30283 & 289 & 917060089 & 514811 \\
\hline 18 & 18 & 29065 & 324 & 844774225 & 523170 \\
\hline 19 & 19 & 29003 & 361 & 841174009 & 551057 \\
\hline 20 & 20 & 29622 & 400 & 877462884 & 592440 \\
\hline 21 & 21 & 28101 & 441 & 789666201 & 590121 \\
\hline 22 & 22 & 29615 & 484 & 877048225 & 651530 \\
\hline 23 & 23 & 28399 & 529 & 806503201 & 653177 \\
\hline 24 & 24 & 29238 & 576 & 854860644 & 701712 \\
\hline 25 & 25 & 31107 & 625 & 967645449 & 777675 \\
\hline 26 & 26 & 25772 & 676 & 664195984 & 670072 \\
\hline 27 & 27 & 22697 & 729 & 515153809 & 612819 \\
\hline Total (S) & 378 & 788235 & 6930 & 23165714237 & 10913871 \\
\hline
\end{tabular}

Dari table diatas dapat diketahui model persamaan regresinya yaitu

$$
Y=30231.66-74.12 X
$$

Pada persamaan diatas dapat diketahui bahwa kata asing cenderung menurun dari minggu ke minggu Berikut ini merupakan bahasan dari analisa kata punah terhadap waktu :

\begin{tabular}{|c||c||c|c|c||c||}
\hline \multicolumn{5}{||c|}{ Tabel Kepunahan kosakata Tiap Minggu . . } \\
\hline \hline No & Waktu (X) & Kata Punah (Y) & $\mathbf{X}^{2}$ & Y $^{\mathbf{2}}$ & XY \\
\hline \hline 1 & 1 & 30161 & 1 & 909685921 & 30161 \\
\hline \hline 2 & 2 & 28930 & 4 & 836944900 & 57860 \\
\hline \hline 3 & 3 & 30034 & 9 & 902041156 & 90102 \\
\hline \hline 4 & 4 & 30292 & 16 & 917605264 & 121168 \\
\hline \hline 5 & 5 & 29405 & 25 & 864654025 & 147025 \\
\hline \hline 6 & 6 & 29344 & 36 & 861070336 & 176064 \\
\hline \hline 7 & 7 & 29475 & 49 & 868775625 & 206325 \\
\hline \hline 8 & 8 & 29412 & 64 & 865065744 & 235296 \\
\hline \hline 9 & 9 & 29486 & 81 & 869424196 & 265374 \\
\hline \hline 10 & 10 & 29476 & 100 & 868834576 & 294760 \\
\hline \hline 11 & 11 & 29611 & 121 & 876811321 & 325721 \\
\hline \hline 12 & 12 & 29522 & 144 & 871548484 & 354264 \\
\hline \hline 13 & 13 & 29752 & 169 & 885181504 & 386776 \\
\hline \hline 14 & 14 & 29341 & 196 & 860894281 & 410774 \\
\hline \hline 15 & 15 & 29607 & 225 & 876574449 & 444105 \\
\hline \hline 16 & 16 & 29615 & 256 & 877048225 & 473840 \\
\hline \hline 17 & 17 & 29482 & 289 & 869188324 & 501194 \\
\hline \hline 18 & 18 & 29646 & 324 & 878885316 & 533628 \\
\hline \hline 19 & 19 & 29658 & 361 & 879596964 & 563502 \\
\hline \hline 20 & 20 & 29553 & 400 & 873379809 & 591060 \\
\hline \hline 21 & 21 & 29858 & 441 & 891500164 & 627018 \\
\hline \hline 22 & 22 & 29523 & 484 & 871607529 & 649506 \\
\hline \hline 23 & 23 & 29794 & 529 & 887682436 & 685262 \\
\hline \hline 24 & 24 & 29844 & 576 & 890664336 & 716256 \\
\hline \hline 25 & 25 & 29407 & 625 & 864771649 & 735175 \\
\hline \hline 26 & 26 & 30157 & 676 & 909444649 & 784082 \\
\hline \hline 27 & 27 & 30671 & 729 & 940710241 & 828117 \\
\hline Total (S) & 378 & 801056 & 6930 & 23769591424 & 11234415 \\
\hline \hline & & & & & \\
\hline
\end{tabular}

Dari table diatas dapat diketahui model persamaan regresinya yaitu

$$
Y=29500.95+11.98 X
$$

Pada persamaan diatas dapat diketahui bahwa kata punah dari minggu ke minggu cenderung meningkat

\section{Kesimpulan}

a. Pada Analisa kemunculan kosakata bahasa Indonesia dapat disimpulkan bahwa penggunaan kata asing dari waktu ke waktu semakin berkuarang namun setelah peneliti mencari penyebab mengapa terdapat kata asing ternyata kata asing pada berita online tersebut dipengaruhi kebanyakan dari nama produk, nama orang, nama perusahaan hingga banyak kata-kata yang dikarenakan salah pengetikan selain itu juga terdapat kata-kata dari bahasa yang memang bukan dari Indonesia. Namun walaupun demikian pertumbuhan kata asing pada berita online dari minggu ke mingu cenderung menurun.

b. Pada Analisa kepunahan kosakata bahasa Indonesia dari minggu ke minggu semakin meningkat hal ini dapat dilihat dari pembahasan untuk kata punah, yang dimaksud kata punah disini merupakan kata-kata bahasa Indonesia yang terdapat pada KBBI namun tidak terpakai pada dokumen berita online. dengan demikian dapat disimpulkan bahwa keragaman kata yang digunakan pada situs berita online dari minggu ke minggu cenderung menurun.

\section{Saran}

Berdasarkan dari penelitian dikarenakan keragaman bahasa Indonesia yang terdapat pada situs berita online semakin menurun maka diharapkan dari berbagai penyedia situs berita online untuk meningkatkan keragaman kata yang digunakan pada berita karena bila keragaman kata yang terdapat pada KBBI apabila tidak sering digunakan maka berangsur-angsur kata tersebut akan menjadi asing bahkan bagi bangsa kita sendiri.

\section{Daftar Pustaka}

Bambang Kurniawan, Syahril Efendi, Opim Salim Sitompul. 2012. "Kasifikasi Konten Berita Dengan Metode Text Mining" Jurnal Dunia Teknologi Informasi Vol. 1, No. 1, (2012) 14-19. Universitas Sumatera Utara.

Saraswati, N. S. (2011). Text Mining Dengan Metode Naivde Bayes Classifier Dan Support Vector Machines Untuk Sentiment Analysis. Tesis Pada Universitas Udayana http://documents.software.dell.com/statistics/textboo k/text-mining 
Volume 3, Edisi 4, Agustus 2017

https://nahulinguistik.wordpress.com/2010/04/19/per geseran-pemertahanan-dan-kepunahan-bahasa/ http://www.pengertianahli.com/2014/07/pengertianregresi-apa-itu-regresi.html 